\title{
Safety Considerations in 3D Bioprinting Using Mesenchymal Stromal Cells
}

\author{
Lucy Belk ${ }^{1,2}$, Nazzar Tellisi1,2,3, Hamish Macdonald4 ${ }^{4}$, Ahmet Erdem ${ }^{5,6,7,8}$, \\ Nureddin Ashammakhi, ${ }^{5,6,9,10,11 *}$ and Ippokratis Pountos ${ }^{1,2,3 *}$
}

${ }^{1}$ Academic Department of Trauma and Orthopaedics, University of Leeds, Leeds, United Kingdom, ${ }^{2}$ School of Medicine, University of Leeds, Leeds, United Kingdom, ${ }^{3}$ Chapel Allerton Hospital, Leeds Teaching Hospitals, Leeds, United Kingdom, ${ }^{4}$ Gloucester Royal Hospital, Gloucestershire Hospitals NHS Foundation Trust, Gloucester, United Kingdom, ${ }^{5}$ Center for Minimally Invasive Therapeutics, University of California, Los Angeles, Los Angeles, CA, United States, ${ }^{6}$ Department of Bioengineering, Henry Samueli School of Engineering, University of California, Los Angeles, Los Angeles, CA, United States, ${ }^{7}$ Department of Chemistry, Kocaeli University, Kocaeli, Turkey, ${ }^{8}$ Department of Biomedical Engineering, Kocaeli University, Kocaeli, Turkey, ${ }^{9}$ Department of Radiological Sciences, David Geffen School of Medicine, University of California, Los Angeles, Los Angeles, CA, United States, ${ }^{10}$ Institute for Quantitative Health Science and Engineering, Michigan State University, East Lansing, MI, United States, ${ }^{11}$ Department of Biomedical Engineering, Michigan State University, East Lansing, MI, United States

\section{OPEN ACCESS}

Edited by:

Julien Georges Didier Barthès,

PROTIP Medical, France

Reviewed by:

Daniela Duarte Campos,

Stanford University, United States

Jae-Won Shin,

University of Illinois at Chicago,

United States

*Correspondence:

Nureddin Ashammakhi

n.ashammakhi@ucla.edu

Ippokratis Pountos

pountos@doctors.org.uk

Specialty section:

This article was submitted to

Biomaterials,

a section of the journal

Frontiers in Bioengineering and

Biotechnology

Received: 07 November 2019

Accepted: 17 July 2020

Published: 08 October 2020

Citation:

Belk L, Tellisi N, Macdonald H,

Erdem A, Ashammakhi N and

Pountos I (2020) Safety Considerations in $3 D$ Bioprinting

Using Mesenchymal Stromal Cells.

Front. Bioeng. Biotechnol. 8:924.

doi: 10.3389/fbioe.2020.00924
Three-dimensional (3D) bioprinting has demonstrated great potential for the fabrication of biomimetic human tissues and complex graft materials. This technology utilizes bioinks composed of cellular elements placed within a biomaterial. Mesenchymal stromal cells (MSCs) are an attractive option for cell selection in 3D bioprinting. MSCs can be isolated from a variety of tissues, can pose vast proliferative capacity and can differentiate to multiple committed cell types. Despite their promising properties, the use of MSCs has been associated with several drawbacks. These concerns are related to the ex vivo manipulation throughout the process of 3D bioprinting. The herein manuscript aims to present the current evidence surrounding these events and propose ways to minimize the risks to the patients following widespread expansion of $3 \mathrm{D}$ bioprinting in the medical field.

Keywords: mesenchymal stromal cells, ex vivo expansion, bioprinting, additive manufacturing, 3D bioprinting

\section{INTRODUCTION}

With an increasing aging population the need to regenerate diseased tissues or replace tissues and organs lost due to trauma or surgery is increasing (Colwill et al., 2008; International Population Reports, 2016). There is already a lack of supply of sufficient organ donations and tissue grafts which is likely to worsen in the future (Yanagi et al., 2017; American Transplant Foundation, 2018). Tissue engineering that was introduced in the last few decades generally employs the seeding of scaffolds with cells (Langer and Vacanti, 1993). This process is associated with inhomogeneous distribution of cells within the scaffold, which can also affect subsequent engineered construct survival, integration and function (Gao et al., 2014). It was previously hypothesized that inhomogeneous seeding could prevent some cells from nutrients and oxygen resulting in poor function (Melchels et al., 2010).

The recent advent of three-dimensional (3D) bioprinting has brought about new possibilities to advance tissue engineering and regenerative medicine. Three-dimensional bioprinting involves the use of cells that are mixed with a carrier material while in liquid form with subsequent solidification of such material by using one of a number of cross-linking techniques. This 
mixture, known as bioink may also include growth factors (Ashammakhi et al., 2019a,b) or other additives such as osteoconductive materials (Byambaa et al., 2017; Ashammakhi et al., 2019c). Three-dimensional bioprinting techniques and bioinks have evolved tremendously over the last two decades, to address the need to create complex biomimetic tissue constructs (Mandrycky et al., 2016; Figure 1).

Cells used in bioinks have represented one of the major challenges faced by tissue engineers because of their limited availability (Freimark et al., 2010), proliferation (Willerth and Sakiyama-Elbert, 2008), and differentiation potential (Tuszynski et al., 2014). While already differentiated cells could be ideal, their harvest can cause donor site morbidity while often perform poorly with ex vivo manipulation. Alternative cell sources of cells include embryonic or reprogrammed cells. These cell types are associated with many challenges (Bongso et al., 2008; Trounson and McDonald, 2015) and concerns. The biggest concern shared by physicians and other care providers, regulatory bodies and industry as a whole is the safety of stem cell therapeutics for use in patients (Goldring et al., 2011). Mesenchymal stem cells on the other hand, have gained popularity and represent a cell type of choice for many experimental and clinical studies in tissue engineering.

\section{MSCs IN 3D BIOPRINTING}

Mesenchymal stromal cells (MSCs) represent one of the most popular types of cells used in tissue engineering today. In fact, their clinical use is so strong today that are used in more than 700 clinical trials listed on US clinical trials. This is because MSCs have potential to differentiate into a wide variety of cell types (Sasaki et al., 2008) but also due of their wide availability from different sources such as the bone marrow (Gnecchi and Melo, 2009), adipose tissue (Katz et al., 2005), blood vessels (Kuznetsov et al., 2001), muscle (Young et al., 1995) as well as rather "embryonic" tissues such as amniotic fluid (Tsai et al., 2004) and cord blood (Bieback et al., 2004). MSCs actively participate in the regeneration of tissues and provide substitute cells for those that expire (Pintus et al., 2018). Following injury MSCs mobilize to distant sites and either provide reparative cells and/or secrete trophic factors to promote healing. In addition, MSCs pose antiinflammatory and immunomodulatory capacity as can improve inflammation and restore or inhibit the functions of immune cells (Pintus et al., 2018). MSCs can be easily expanded ex vivo to provide clinically relevant numbers prior to use. Although their exact function is not fully elucidated, MSCs have been used widely in tissue engineering instead of pluripotent stem cells (embryonic or induced pluripotent stem cells) which possess their own concerns and more complex processing techniques (Porada et al., 2006).

In 3D bioprinting, MSCs remains a popular cell type for the use in bioink. Their use is not limited to bone (Ong et al., 2018), cartilage (Bae et al., 2018), and adipose tissue (Qi et al., 2018) but MSCs are considered and used in many other 3D bioprinting applications. In fact, in addition to bone and cartilage, MSCs were used in 3D bioprinting of muscle (Phillippi et al., 2008), aortic valve (Kang et al., 2017), cardiovascular tissue (Ryu et al., 2015), neural tissues (Jakab et al., 2010), tendons and ligaments (Rak Kwon et al., 2020), and others (Tasnim et al., 2018). Thus, the objective of this review is to examine the literature on 3D bioprinting that utilized MSCs and examine accumulated data pertaining to the safety of MSCs in $3 \mathrm{D}$ bioprinting in various pre-, intra-, and post-printing stages. Discussion of findings is included, challenges highlighted, and future directions are outlined.

\section{PRE-PRINTING}

The generation of reliable MSC-based 3D bioprinting products requires first an in-depth understanding of the MSC physiology. MSC physiology is complex and it is influenced by the local microenvironment. For example, some researchers have shown that MSCs have tumor-suppressing properties (Khakoo et al., 2006; Cousin et al., 2009; Ho et al., 2013). On the contrary, MSCs can also favor tumor progression by promoting tumor angiogenesis, maturation of tumor vasculature and expansion through the secretion of a wide range of bioactive biomolecules (Kucerova et al., 2010; Suzuki et al., 2011; Huang et al., 2013). The reason for such dual roles is largely obscure. Together with MSC physiology, the target tissue micro-architectural topography, physiology, mechanical properties have to be elucidated. This will dictate the porosity, stiffness, orientation of the scaffold components and depict the exact location of the cellular components (Daly et al., 2017).

In addition to robust understanding of MSC physiology, further work on developing methodologies that safeguard high viability and ensure safety of grafts is needed. Literature suggests that the success of potential application of MSCs is closely related to the number of MSCs (Hernigou et al., 2005a,b). The expansion of the cells raises several concerns involving the extent of the expansion (expansion induces deprivation of MSCs properties), the effect of culture conditions, culture media and tissue culture plastics on the cells as well as the effect of cryopreservation on MSCs (Sotiropoulou et al., 2006; Pountos et al., 2007). The need for supplementation of the culture media with cytokines and chemokines in high non-physiologic concentrations is unknown whether it can affect their long-term properties. Worrying reports are available suggesting, that ex vivo expansion of MSCs can induce spontaneous malignant transformation into cells with tumorigenic potential (Rubio et al., 2005). Even more disturbing are the reports of occasional sarcoma formation in patients receiving bone marrow treatment and those undergone autologous fat graft (Perrot et al., 2010).

\section{PRINTING PROCESS}

\section{Characteristics of 3D Bioprinting Methods in Brief}

There are several 3D printing techniques among which the most commonly used for 3D bioprinting are extrusion, laser-based (Catros et al., 2011), inkjet (Cui et al., 2010), stereolithography 



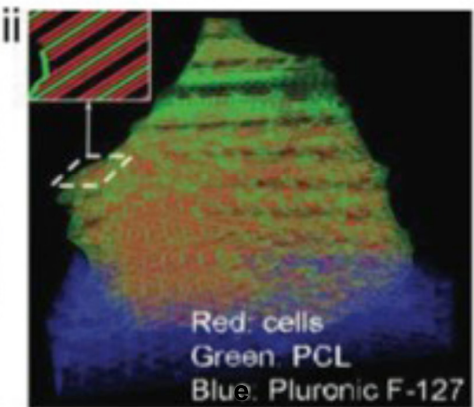

iv

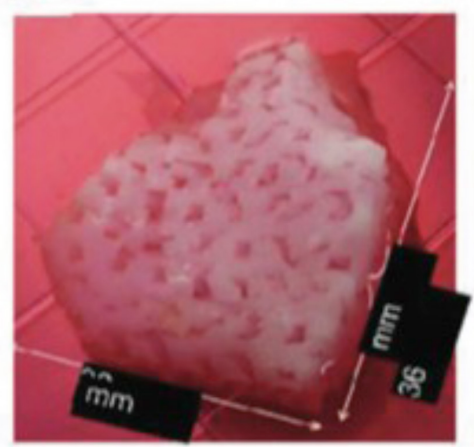

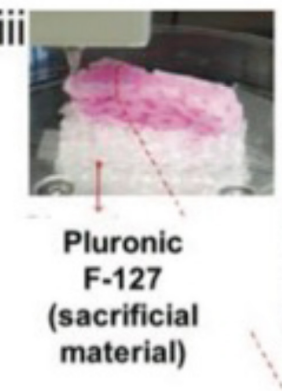

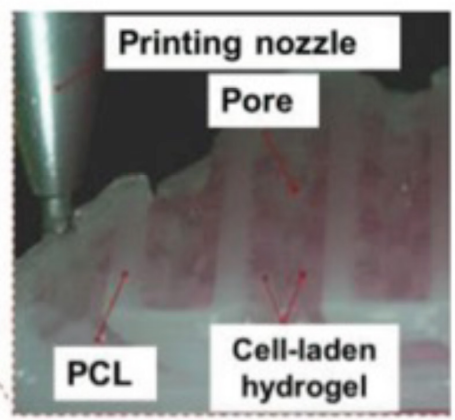

v

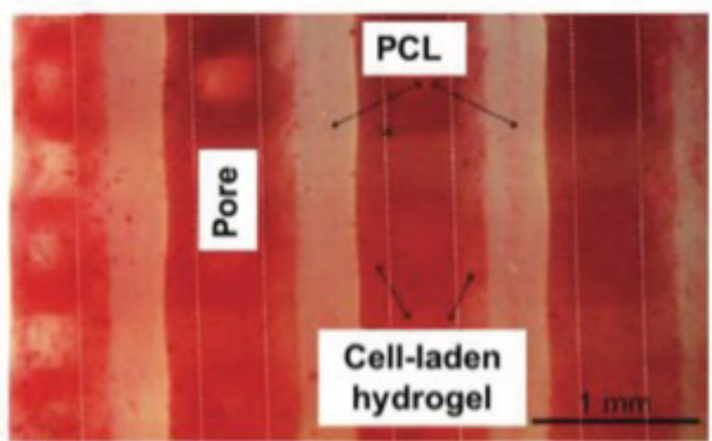

FIGURE 1 | The pathway of creating complex 3D printed structures. (i) Modeling of a mandibular defect with the use of patients CT scans. (ii) Construction of 3D architecture. (iii) 3D printing process. (iv) Culture of the graft. (v) Differentiation of the cells to osteoblasts. Reproduced with permission from Kang et al. (2016).

(Wang et al., 2015) and electrospinning-based printing (Khalil and Sun, 2009; Wüst et al., 2011; Dababneh and Ozbolat, 2014; Figure 2). The same technologies can be used to create smart 3D-bioprinted structures able to respond to the environment; commonly referred to as four-dimensional (4D) bioprinting (Figure 3). Extrusion 3D bioprinting or pressureassisted bioprinting uses hydrogel bioinks extruded from a syringe in a continuous trace through a fine nozzle (Maher et al., 2009; Bhuthalingam et al., 2015; Irvine et al., 2015). In most extrusion bioprinters, the nozzle can move on $y-z$ axes with the substrate collector plate moving in the $x$-axis to produce the final structure (Maher et al., 2009; Bhuthalingam et al., 2015; Irvine et al., 2015). Extrusion bioprinting delivers good homogeneity of bioinks, can deliver very high cell densities and does not require any specific environmental conditions (can be carried out at room temperature) (Atala and Yoo, 2015; Bishop et al., 2017). The overall resolution is rather poor compared to other techniques (minimum feature size is generally over $100 \mu \mathrm{m}$ ) (Leberfinger et al., 2017). Despite this, the technique has been used to create complex structures but MSCs survival was as low as $40 \%$ due to apoptosis and cell deformation.

Laser bioprinting uses a pulsed nanosecond or ultraviolet (UV) like wavelength laser as a source of energy to stimulate the upper surface of an energy absorbing metal film, which is usually made of a layer of titanium or gold (Catros et al., 2011). This metal film is coated with bioink on its lower surface and acts as a donor film. Stimulation of the upper surface of the metal film causes vaporization, creating a pressure bubble that drives the bioink from the donor film onto a substrate plate containing a biopolymer (Stolberg and McCloskey, 2009; Jana and Lerman, 2015; Irvine and Venkatraman, 2016; Li et al., 2016). The biopolymer functions to aid in sustaining growth and cellular adhesion of the cells after transfer from the donor film (Catros et al., 2011; Trombetta et al., 2017). The precise resolution is influenced by a number of factors including the energy emitted by the laser, printing speed, viscosity and thickness of the bioink layer on the donor film and its rheological properties, shape and organization of the structure and substrate wettability (Guillemot et al., 2010a,b; Li et al., 2016). Despite that, this is a scaffoldfree technique reaching resolutions between 10 and $50 \mu \mathrm{m}$. Some studies managed to achieve a resolution of a single cell per droplet. This method negates the shearing stress experienced by cells during deposition down a narrow print head or nozzle (Murphy and Atala, 2014; Mandrycky et al., 2016; Keriquel et al., 2017). The potential of laser bioprinting has been demonstrated in a number of studies (Barron et al., 2004; Guillemot et al., 2010a,b).

Inkjet bioprinting arose from the adaptation of conventional desktop inkjet printers. It is a noncontact printing process where a droplet of bioink is deposited through the print head on demand, under the control of a thermal or piezoelectric actuator. This type of multi-cell printing is known as drop on demand (Irvine and Venkatraman, 2016). The resolution is in the region of up to $50 \mu \mathrm{m}$ (Mandrycky et al., 2016). Thermal actuation is the more commonly used method for inkjet bioprinting where droplets of bioink are generated by an electric current. The 


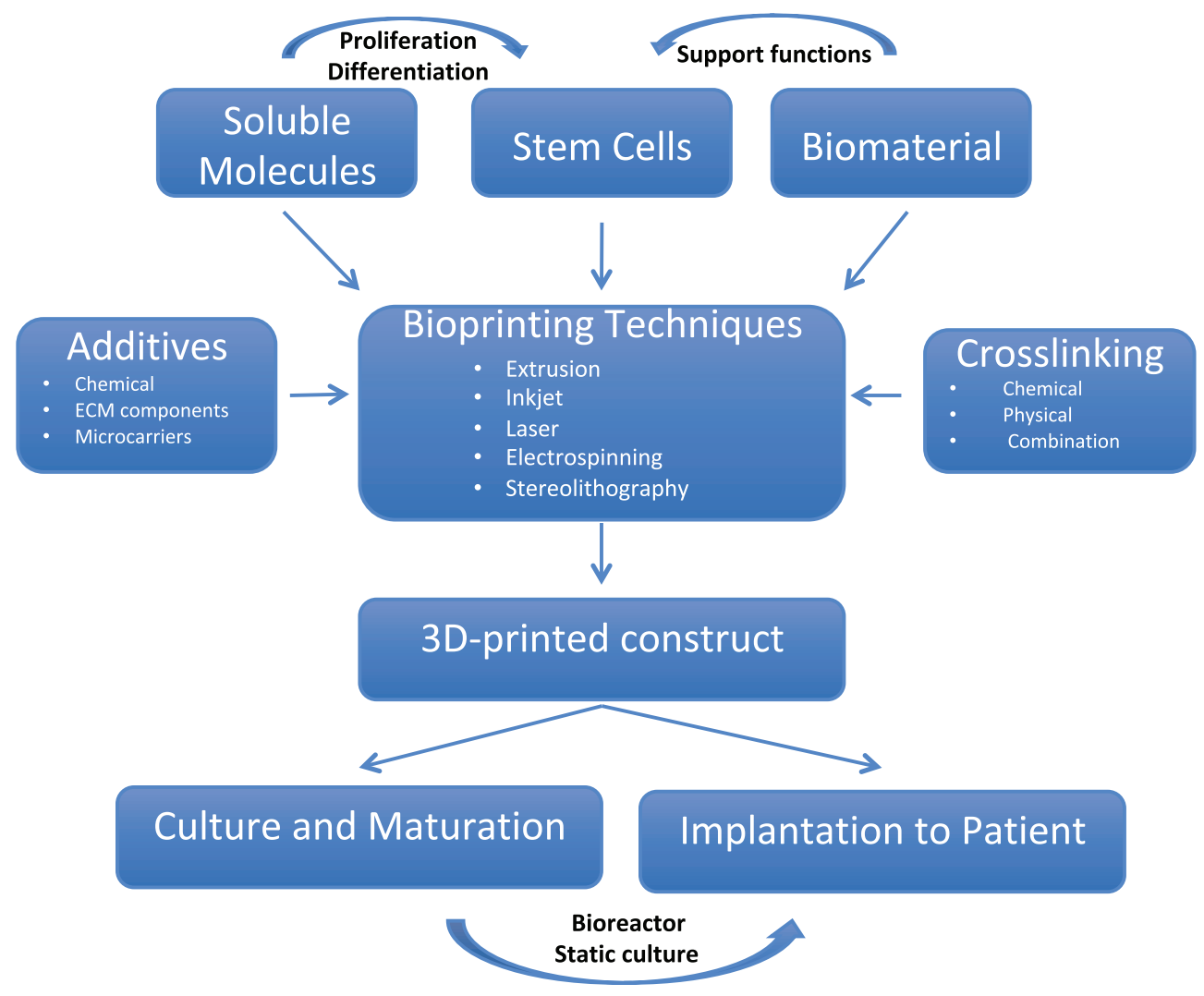

FIGURE 2 | The pathways and components of 3D bioprinting process.

thermal actuator element reaches temperatures in excess of up to $300^{\circ} \mathrm{C}$, allowing a vapor bubble to generate sufficient pulse pressure to expel the bioink from the print head (Cui et al., 2010). This could potentially impart both shear and thermal stress on the cells (Irvine and Venkatraman, 2016; Li et al., 2016). The requirement to use low viscosity inks to prevent blockage of the print-head prevents the use of a number of efficacious bioinks. In contrast to the thermal, the piezoelectric actuation produces a transient pressure to eject the droplets on to the substrate. It produces more homogenous droplets than thermal actuation, but some authors reported greater levels of cell damage (Seetharam, 1991; Nakamura et al., 2005; Saunders et al., 2007).

Stereolithography is another 3D bioprinting technique that can be used to generate $3 \mathrm{D}$ constructs. This technique involves the solidification of a cell-laden photo-crosslinkable polymer solution in a layer-by-layer fashion, and it is controlled by a moveable stage along the $z$-axis (Murphy and Atala, 2014). In stereolithography, 3D complex structures can be produced without the need for a printhead that moves in $x-y$ direction. In this process, a digital micromirror device (DMD) which allows highly precise patterns to be created, is used to control selectively crosslinking of bioink in $\mathrm{z}$ direction (Heinrich et al., 2019). This selective crosslinking method by light does not lead to any cell shear stress, making it possible to achieve higher cell viability in produced constructs. However, the use of transparent bioinks is required in stereolithography in order to achieve uniform crosslinking. This restricts the cell density that can be used in the bioink (Minteer et al., 2013). Despite this limitation, the technique has a great potential because of high speed, high resolution $(\sim 1 \mu \mathrm{m})$ and controllability of the internal and external architecture of the resulting construct (Gruene et al., 2011a,b; Kang et al., 2017).

Electrospinning is a high-resolution fabrication method that can be used to produce thin fibers (Heinrich et al., 2019). During the process of electrospinning, a high voltage is applied to the ejected polymeric solution from the syringe. When the electrostatic repulsion starts to overcome the surface tension of the solution, the solution begins to evaporate and it is subsequently solidified during transit to form fibers (Ashammakhi et al., 2008; Bhardwaj and Kundu, 2010). Thin fiber-based constructs can be produced by this technique. Recently, this process technique has been modified for bioprinting by adding cells and controlling the process of fiber arrangement in the resulting structure. One of the primary features of electrospinning-based bioprinting (EBB) is the shorter collecting range of fibers (around 0.5-3 $\mathrm{mm}$ ) in comparison to traditional electrospinning. This allows for more controllable deposition of electrospun materials with less applied voltage than usually used in conventional electrospinning (Heinrich et al., 2019). Visser et al., 2015; have recently used electrospinning-based bioprinting 

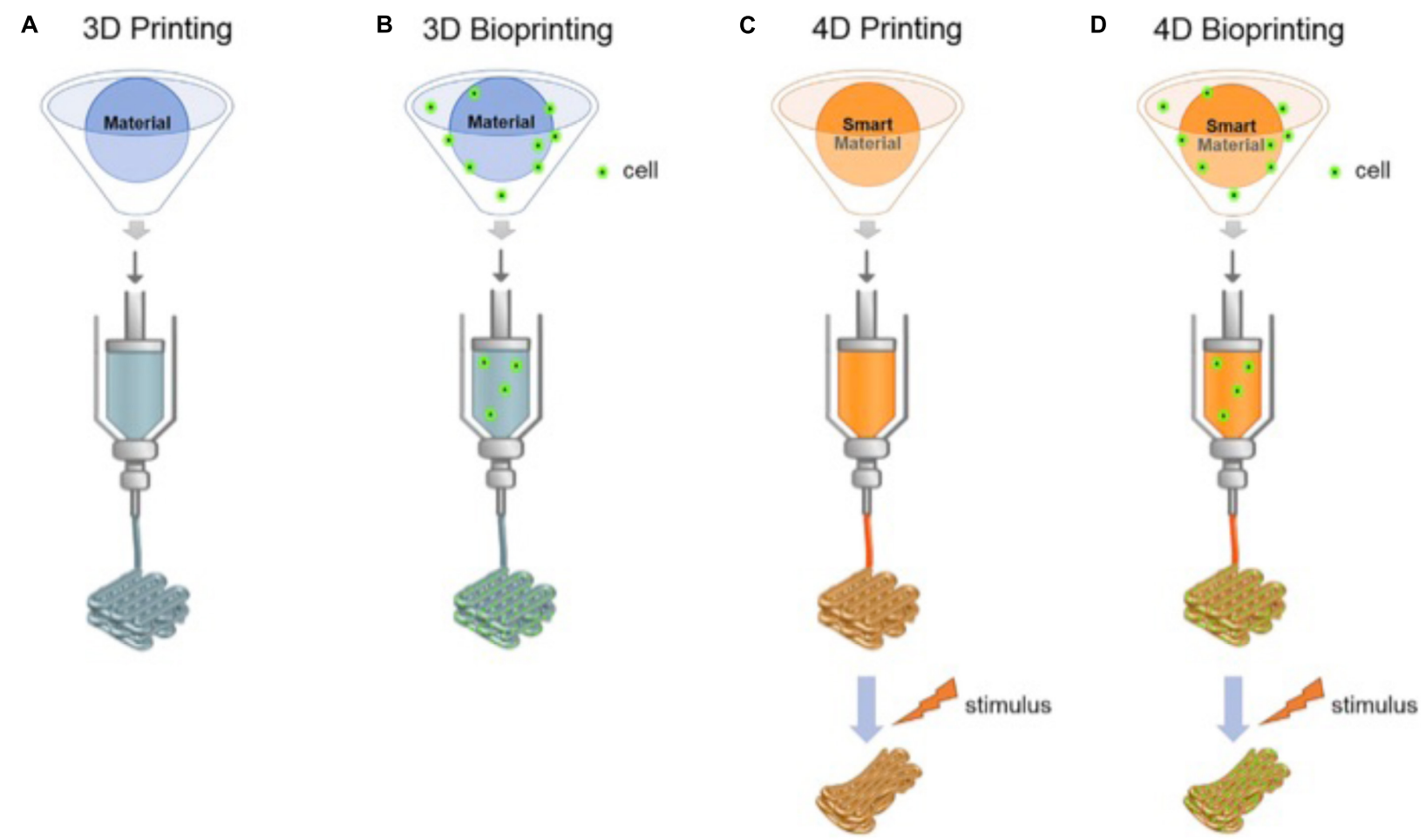

FIGURE 3 | The different printing technologies (3D, 3D bioprinting, 4D, and 4D bioprinting). (A,B) shows conventional 3D printing and bioprinting techniques. (C,D) For-dimensional bioprinting is defined as 3D printing of cell-laden materials in which the printed structures would be able to respond to external stimulus due to stimuli-responsive bioinks or internal cell forces. Reproduced with permission from Ashammakhi et al. (2018).

technology to enhance GelMA hydrogel mechanical strength by reinforcing high-porosity poly( $\varepsilon$-caprolactone) (Visser et al., 2015). The rigidity of GelMA hydrogels increased 30 times by $7-214 \mathrm{kPa}$ while its elastic properties were preserved (Visser et al., 2015). However, the main restrictions of $\mathrm{EBB}$ are the fast spinning of fibers, resulting in a spatially unstable $3 \mathrm{D}$ structures and the high processing temperature and voltage, which is challenging to cells contained in the electrospun material.

\section{Cell Death During 3D Bioprinting}

The viability of the cells can be influenced by a number of factors. These include the storage of the cells in the printer, the thermal damage during the printing process and the mechanical forces exerted during bioprinting. Table 1 shows documented survival rates following $3 \mathrm{D}$ bioprinting.

Cell storage and conditions during the printing process can potentially affect cell viability. During this process the cells are required to be stable and in media that could allow them to recover from the effects of cells-detaching solution (i.e., Trypsin, TrypLE, collagenase or others) and the stress exerted on them during the detachment process (i.e., centrifugation, washing, etc.). It is known that these methods can affect cell survival, phenotype and differentiation potential (Parvin et al., 2012; Tsuji et al., 2017). In addition, the effect of prolonged bioprinting protocols would require stable media and stable cell conditions. At present, there are limited studies in this field.
Thermal injury to cells is another area of concern. For example, during inkjet printing, where temperatures exceed 200 $\circ$, studies have shown that the bioink temperatures are raised by just $4-10^{\circ}$ (Cui et al., 2010) and this does not significantly adversely affect the viability of mammalian cells (Suzuki et al., 2011). This heating effect is thought to be temporary ( $\sim \mu \mathrm{s})$, with less than $8 \%$ of the cells being lysed during bioprinting (Cui et al., 2010). Similar results were reported for the heat shock of the laser pulse where the cell survival, proliferation and differentiation were comparable to those of controls at 5 days in cell culture (Gruene et al., 2011b).

In addition to the potential thermal damage, the mechanical stress should be also taken into account. Cells are known to respond to mechanical stress by changing their gene expression and cell function. Among many cells' adaptation mechanisms activated, MSCs activates several intracellular signaling cascades, including kinases (PKB, MAPK, FAK), $\beta$-catenin, GTPases (Thompson et al., 2012). Chang et al. (2008), found that cellular viability is inversely related to extrusion pressure, with as little as $40 \%$ viability found at the extremes of high pressure. Mechanical pressure observed in inkjet printing has been demonstrated to promote the differentiation of MSCs toward bone and cartilage lineages (Shav and Einav, 2010). In contrast, the shear stress produced in extrusion techniques promotes differentiation toward both endothelial and bone tissues (Stolberg and McCloskey, 2009). The choice of the 3D technology is mostly done on the basis of required resolution and the target tissue as 
TABLE 1 | Studies presenting the survival rates of cells used as bioink for 3D-bioprinting applications.

\begin{tabular}{|c|c|c|c|}
\hline Author, year & 3D Printer & Cell types & Survival rates \\
\hline
\end{tabular}

\section{Inkjet bioprinting}

Christensen et al. (2015) Thermal inkjet printing

Saunders et al. (2007) Piezoelectric drop-on-demand inkjet printing

Cui et al. (2010)

Thermal inkjet printing

Christensen et al. (2015) Inkjet based free form fabrication

Levato et al. (2014) Bioscaffolder system (Levato et al., 2014)

Du et al. (2015)

Inkjet with four independent $z$-axis-controlled ink reservoirs

\section{Extrusion bioprinting}

Zhao et al. (2014)

Microextrusion printing

Zhao et al., 2015

Four nozzle microextrusion printing

\section{Laser assisted bioprinting}

$\begin{array}{ll}\text { Barron et al. (2005) } & \text { BioLPTM Biological Laser Printing } \\ \text { Koch et al. (2010) } & \begin{array}{l}\text { Laser based printing based on laser } \\ \text { assisted forward transfer (LIFT) }\end{array}\end{array}$

Hopp et al. (2012) Femtosecond KrF laser in laser assisted forward transfer (LIFT)
A549 cells

Chinese hamster ovary cells and primary embryonic motor neurons from ventral cords of 14-day embryos from pregnant Sprague-Dawley rats

HT 1080 human fibroblasts

Green fluorescent protein expressing

Chinese hamster ovary cells

NIH 3T3 mouse fibroblasts

Mesenchymal stem cells from 2 to 4 weeks old Lewis rats

Bone mesenchymal stem cells from 4-weeks-old male adult Sprague-Dawley rats

HeLa cells

Human osteosarcoma cells

Skin cell lines (fibroblasts, keratinocytes); Human mesenchymal stem cells

Human neuroblastoma, chronic myeloid leukemia and osteogenic sarcoma cell lines and primary astroglial rat cells

Greater than $90 \%$ cellular viability after printing.

Cellular survival of $94-98 \%$.

Average cellular viability was $89 \%$

Post printed cellular viability was $92.4 \%$

immediately after printing and $90.8 \%$ after $24 \mathrm{~h}$ of incubation.

Post dispensing viability was $80 \%$ after 1 day and more than $90 \%$ after 3 days.

Cellular viability of $>90 \%$ was seen during printing

Post printed viability of the HeLa cells in constructs was $94.9 \% \pm 2.2 \%$ with parameters of $10 \mathrm{~mm}^{3} \mathrm{~min}^{-1}$ extrusion speed, $250 \mu \mathrm{m}$ nozzle inner diameter, $10^{\circ} \mathrm{C}$ chamber temperature and $25^{\circ} \mathrm{C}$ nozzle temperature. Cell survival rate was > 90\% for all rheological conditions at a holding temperature of $20^{\circ}$

After six days of incubation, cells demonstrated a $100 \%$ viability

$98 \% \pm 1 \%$ standard error of the mean (skin cells) and $90 \% \pm 10 \%$ (hMSC).

Short-term and long-term survival for

neuroblastoma and astroglial cells was

$65-70 \%$. Long term survival of osteosarcoma cells was low, while myeloid leukemia cells did

not tolerate the procedure under the conditions.
Survival rates decrease with increased printing pulse amplitude. Sampled printed at $40 \mathrm{~V}$ demonstrated survival rates that could not be distinguished from unprinted control samples.

No significant difference in viability was observed in different cellular concentrations of ink. Printed cell number correlated with increasing cellular ink concentrations.

Pre-seeded particles suspended in the gels had the lowest number of viable cells (60\%) after 1 day of culture, which increased to $90 \%$ after 3 days.

CBD-BMP2-collagen microfibers induced BMSC differentiation into osteocytes within 14 days more efficiently than the osteogenic medium.

Comparisons of $3 \mathrm{D}$ and $2 \mathrm{D}$ tumor models of HeLa cells show a higher cellular proliferation rate and more simulated tumor characteristics with $3 \mathrm{D}$ printing

For all concentrations of bioink used in microextrusion printing, a holding temperature of $20^{\circ}$ should be used. Optimum holding times were variable, dependent upon bioink concentration

No increase in apoptosis or DNA fragmentation was seen with the use of LIFT. hMSC phenotype was maintained as proven by fluorescence activated cell sorting analysis. 
well as other factors. Lee et al. (2015) suggested that laser assisted and inkjet bioprinting may be preferable to extrusion bioprinting in most circumstances, but where circumstances necessitate the use of bioink with a high viscosity, extrusion bioprinting may be necessary. In these circumstances, the effects of sheer stress may be countered by modification of the bioink composition, e.g., by the inclusion of thinning polymers and the control of back pressure during the printing process (Mackay et al., 1998).

\section{Bioink Characteristics and Cellular Adhesion}

The primary aim in preparing a bioink is the biomimicry of the extracellular matrix, which creates a microenvironment that is optimal for cellular adhesion, proliferation and differentiation. An ideal bioink will maintain its printed structure integrity, be crosslinkable and can undergo degradation. It must accommodate cells, and sustain their integrity and viability throughout the printing process (Irvine and Venkatraman, 2016; Grungor-Ozkerim et al., 2018). It should also have the specific mechanical, physicochemical, rheological and biological properties needed for printability and for the preservation of cellular phenotype (Byambaa et al., 2017). Skardal and Atala (2015) highlighted that most biocompatible bioinks which were able to bear the vertical weight of emerging structures either produced toxic macromolecules during the setting process or required a toxic solvent for setting itself.

Porosity and interconnectivity are also two essential factors. Pore size, shape and volume are all influential in the behavior of cells following adhesion to the scaffold structure. Matsiko et al. (2015), found that pore size correlates with cellular organization, mineralization and the development and assembly of collagen I. Greater porosity and more interconnectivity allow for better matrix deposition and transportation of oxygen and other essential substrates into the center of the scaffold, promoting better ingrowth of tissue. Domingos et al. (2013), concluded that the morphology of printed cells did not appear to be influenced by the topology of pores, but that cell viability and proliferation were strongly affected by the size and shape of the pores, with large quadrangular pores resulting in the best viability and proliferation of human MSCs.

Scaffold stiffness has also been noted to play an integral role in the terminal differentiation of cells. MSCs have been observed to differentiate into cell types that best fit the microenvironment supported by the mechanical properties of the attachment surface or matrix. Differentiation toward an osteogenic lineage is observed in cells adhering to a rigid surface $(34 \mathrm{kPa})$, compared with a more elastic surface $(0.1-1 \mathrm{kPa})$, where MSCs display a tendency to differentiate toward a neuronal lineage (Engler et al., 2006; Lane et al., 2014). In relatively soft hydrogels (2.5-5 kPa), a differentiation toward adipogenesis is observed (Arany et al., 2010). This offers the possibility for the modification of bioink matrices and scaffolds to induce a specific lineage differentiation. Gao et al. (2015), produced a bioink that was optimized for bone and cartilage regeneration. The ink, made from a hybrid of polyethylene glycol and gel dimethylacrylate, had a compressive modulus of 1-2 $\mathrm{MPa}$ when printed, significantly 
stiffer than previously used hydrogels. MSCs printed in this hydrogel demonstrated a greater propensity toward osteocyte and chondrocyte lineage (Gao et al., 2015), but only in the context of specific extracellular matrix (Rowlands et al., 2008) and cross-linking conditions (Das et al., 2015).

It has been previously suggested that a scaffold can guide MSCs toward a specific lineage. In cases where the aim is to maintain stemness, bioinert hydrogels should be used. This avoids creating an environment that may be favorable to one particular lineage of cells. One such example of a bioinert hydrogel is alginate (Irvine and Venkatraman, 2016) which retains the stemness of printed stem cells (Blaeser et al., 2016). However, caution must be exercised when using bioinert hydrogels, as proliferative capabilities and movement are reduced, which may promote anoikis (Carrow et al., 2015), however, this may be overcome by the addition of the integrin binding peptide arginyl-glycyl-aspartic acid (RGD) moieties to bioinert alginates which increases cellular interaction whilst maintaining stemness (Carrow et al., 2015). Hyaluronic acid is an alternative to alginate, with proven clinical efficacy (Ozbolat and Hospodiuk, 2015). In contrast to alginate, hyaluronic acid promotes MSC attachment and maintains multipotency and proliferation through CD44 receptors (Cao et al., 2016), with the added benefit of adaptation to promote a specific lineage differentiation. One such example is the use of hyaluronic acid in cardiogenesis (Mairim et al., 2012). Where bioinert inks have been used, MSCs can be differentiated by incubation with soluble factors that direct maturation to a specific lineage in a similar fashion to culture additives (Irvine and Venkatraman, 2016). To remove reliance on extrinsic factors, additives can be included in bioink. For example, alginate bioinks have been modified with the addition of hydroxyapatite in the context of bone regeneration (Wüst et al., 2014). In vivo murine models of alginate scaffolds containing biphasic calcium phosphate particles (consisting of hydroxyapatite and $\beta$-tricalcium phosphate) displayed greater osteogenic differentiation than scaffolds having no biphasic calcium triphosphate (Wang et al., 2007).

\section{The Effect of Cross-Linking}

Three-dimensionally bioprinted extracellular matrix may lack the required stability and integrity to support contained cells. Crosslinking is often an essential step and a number of physical, biological and chemical crosslinking techniques have been proposed over the years. The aim of these techniques is to enhance the mechanical and biological properties of the grafts preventing the cell-mediated contraction. Crosslinking induces chemical or physical links between the polymer chains of the scaffold and can be achieved by using UV light, dehydrothermal treatment, or treatment with sodium citrate, sodium tripolyphosphate, sulfosuccinic acid, oxalic acid, glutaraldehyde, genipin, or carbodiimide (Lew et al., 2007; Pfeiffer et al., 2008; Jóźwiak et al., 2017; Vining et al., 2019).

Crosslinking can affect several of the cellular functions, including proliferation, differentiation and cellular ability to attach to a scaffold (Davidenko et al., 2015). Kim et al., investigated the effect of different crosslinking techniques on immortalized human corneal epithelial cells, human skin fibroblasts, primary bovine corneal endothelial cells and immortalized human retinal pigment epithelial cells (Kim et al., 2014). The authors reported different toxicity levels with the least toxic being with mononitroalcohols and glyceraldehide, intermediate toxicity being with nitrodiol and nitrotriol, and highest toxicity being with glutaraldehyde, paraformaldehyde, genipin, and bronopol. Several studies have also defined the critical concentration over which the agent induces cytotoxic effect (Wang and Stegemann, 2011; Muzzarelli et al., 2015). On the contrary, some studies suggest that crosslinking can have a positive effect on cellular function. Raucci et al. (2015), studies the effect of citric acid crosslinked cellulose containing hydrogel on the osteogenic differentiation of MSCs. The authors revealed enhanced hydrophilicity and roughness of the hydrogel together with a stimulation of osteogenic differentiation as demonstrated by enhanced expression of bone markers such as osteopontin and osteocalcin. In addition to the direct effect of the crosslinking on MSCs, the physical properties of the extracellular matrix can regulate the response and phenotypes of the cells (Kyle et al., 2019).

Despite many promising studies, to date, there is no gold standard method for cross-linking 3D printed biomimetic materials. In cases where multiple bioinks are used, tuning the scaffold microstructure through crosslinking of multiple biomaterials without affecting its properties will require significant improvement in our 3D printing technology. In tissues where biodegradation or regeneration is required, like for example in $3 \mathrm{D}$ bioprinting of bone, the mechanical properties of scaffolds are negatively correlated with their biodegradation profile (Oryan et al., 2018). Finally, one major concern is the potential inflammatory reaction following implantation. It is shown that the cross-linking methods can induce an immune reaction, initiate M1 macrophage response and inhibition of M2 macrophage polarization, reduced cell infiltration, increased proinflammatory cytokine expression and peri-implantation fibrosis (Delgado et al., 2015), which should be carefully considered and solutions devised.

\section{POST-PRINTING}

Following 3D printing, cell-laden scaffolds will require incubation prior to implantation. This raises the question of how the nutrients and wastes will be exchanged to support the cells until implantation. For a thin construct, this can be done through a static culture through diffusion; however, functioning vasculature will be required for larger constructs. Dynamic culturing can provide continuous infiltrating flow of medium and/or compressive/tensile loading, which is most beneficial for cartilage and bone tissue engineering (Butler et al., 2009). In case the technology reaches the stage of creating vasculature (Shahabipour et al., 2020), research would be needed to determine if blood would be an adequate medium to facilitate nutrients and waste exchange.

In addition to the nutrient supply, cells will require time to attach onto the scaffold. It has been previously shown that post-fabrication incubation for long periods can increase the 
mechanical strength of the construct due the function of the cells and further tissue development (Butler et al., 2009). If photopolymerization is used to harden the bioink, it is unknown whether it can cause cytotoxicity due to the photoinitiators and ultraviolet light. Visible light-sensitive photoinitiators are reported to cause less cytotoxicity but this area is poorly explored (Lim et al., 2016; Mondschein et al., 2017).

\section{Future Directions and Conclusion}

Three-dimensional bioprinting technology has achieved growing popularity for its favorable potential. There is impressive progress with the pertinent techniques supporting the view that in the near future organ manufacturing will be a reality. Threedimensional bioprinting can find application in organ and graft transplantation by overcoming the issues of immune rejection and reducing the cost of grafts and could be used to establish platforms for research and drug screening.

MSCs are one of the most popular cell type in tissue engineering and are involved in more than half of the clinical trials since 2000 (Yuan et al., 2019). These cells are most likely to be the main component of $3 \mathrm{D}$ bioprinting. In order to preserve and deliver MSCs advantages, it is essential to mimic there in vivo microenvironment throughout the $3 \mathrm{D}$ biofabrication process (Baker and Chen, 2012). In addition, the availability of nutrients and oxygen remains high and similar to that in the body (Melchels et al., 2010; Ashammakhi et al., 2020). This seems to be the only way for the cells retain their phenotype, adhesion, metabolism, and response signaling (Baker and Chen, 2012).

Despite the great progress we have seen in understanding the biology of target tissues in humans, our knowledge is still based on animal biology. Understanding MSC biology is also crucial and it is in fact the most difficult challenge. This will allow us to direct the efforts creating more physiologically relevant structures. MSCs for example could be used in high densities when creating biomimetic cartilage and bone tissues or in lower densities as supporting cells in other applications. Before, however, we are in a position to discuss such matters we would have to decode our biology in health and disease in humans raises significant ethical issues. Once $3 \mathrm{D}$ bioprinting reaches a position of manufacturing complex biomimetic tissues, such as organs and large grafts, an appropriate regulatory framework will be required. Hints that this is imminent are shown in many studies which produced complex grafts. Ethical issues include the

\section{REFERENCES}

American Transplant Foundation (2018). American Transplant Foundation. Available at: www.americantransplantfoundation.org (accessed November 7, 2019).

Arany, P. R., Shvartsman, D., Huebsch, N., Mao, A. S., Ali, O. A., Bencherif, S. A., et al. (2010). Harnessing traction-mediated manipulation of the cell/matrix interface to control stem-cell fate. Nat. Mater. 9, 518-526. doi: 10.1038/ nmat 2732

Arcaute, K., Mann, B., and Wicker, R. (2006). Stereolithography of threedimensional bioactive poly(ethylene glycol) constructs with encapsulated cells. Ann. Biomed. Eng. 34, 1429-1441. doi: 10.1007/s10439-0069156-y ownership of prototypes, the harvesting and type of cells and biomaterials, research as well as commercialization of produced constructs. Regulation in terms of safety is also needed including the biocompatibility of bioinks, long-term safety of grafts and the ex vivo manipulation of cells.

The optimal ex vivo conditions prior to printing should be established. In our view, minimizing the ex vivo journey of the cells is crucial. Harvesting and printing the cells in the same sitting could only be done with knowledge of specific markers for MSC, which we lack at present. This is feasible for other cell types with, such as for example the hematopoietic stem cells, which are currently used without manipulation in cancer patients following whole body irradiation (Bazinet and Popradi, 2019). For MSCs however, at present there is a lack of robust techniques for cell isolation and purification that do not affect MSCs biology and then cell preservation strategies. To this end, one of the major drawbacks is the unavailability of reliable culture media, as current research is merely based on animal derived sera. Serum free media or the use of autologous serum can be an alternative but further research is needed in this matter. In addition, the identification of biomimetic matrices mimicking the native tissue composition and allowing cellular growth and differentiation is required. Finally, conditions under which the $3 \mathrm{D}$ constructs will survive following printing potentiate dangers and can jeopardize the whole process. A solution would include developing new bioinks and bioprinters that allow high-resolution fabrication process would diminish the need for post-fabrication culture. Only addressing the aforementioned challenges will safeguard the feasibility and safety of 3D bioprinting for regenerative medicine applications.

\section{AUTHOR CONTRIBUTIONS}

LB, NT, HM, AE, NA, and IP contributed to the research, writing, editing and formatting of the manuscript. All authors contributed to the article and approved the submitted version.

\section{FUNDING}

AE acknowledges funding from TUBITAK-2219 (1059B19170 0093).

Ashammakhi, N., Ahadian, S., Darabi, M. A., El Tahchi, M., Lee, J., Suthiwanich, K., et al. (2019a). Minimally invasive and regenerative therapeutics. Adv. Mater. 31:e1804041.

Ashammakhi, N., Hasan, A., Kaarela, O., Byambaa, B., Sheikhi, A., Gaharwar, A. K., et al. (2019b). Advancing frontiers in bone bioprinting. Adv. Healthc. Mater. 8:e1801048.

Ashammakhi, N., Ahadian, S., Xu, C., Montazerian, H., Ko, H., Nasiri, R., et al. (2019c). Bioinks and bioprinting technologies to make heterogeneous and biomimetic tissue constructs. Mater. Today Bio 1:100008. doi: 10.1016/j.mtbio. 2019.100008

Ashammakhi, N., Ahadian, S., Zengjie, F., Suthiwanich, K., Lorestani, F., Orive, G., et al. (2018). Advances and future perspectives in $4 \mathrm{D}$ bioprinting. Biotechnol. J. 13:e1800148. 
Ashammakhi, N., Darabi, M. A., Kehr, N. S., Erdem, A., Hu, S. K., Dokmeci, M. R., et al. (2020). Advances in controlled oxygen generating biomaterials for tissue engineering and regenerative therapy. Biomacromolecules 21, $56-72$.

Ashammakhi, N., Ndreu, N., and Wimpenny, Y. (2008). Advancing tissue engineering by using electrospun nanofibers. Regen. Med. 3, 547-574. doi: 10.2217/17460751.3.4.547

Atala, A., and Yoo, J. J. (2015). Essentials of 3D Biofabrication and Translation [Internet]. San Diego, CA: Elsevier Scienc.

Bae, S. W., Lee, K. W., Park, J. H., Lee, J., Jung, C. R., Yu, J., et al. (2018). 3D bioprinted artificial trachea with epithelial cells and chondrogenicdifferentiated bone marrow-derived mesenchymal stem cells. Int. J. Mol. Sci. 19:1624. doi: 10.3390/ijms19061624

Baker, B. M., and Chen, C. S. (2012). Deconstructing the third dimension how 3D culture microenvironments alter cellular cues. J. Cell. Sci. 125(Pt 13), 3015-3024. doi: 10.1242/jcs.079509

Barron, J., Krizman, D., and Ringeisen, B. (2005). Laser printing of single cells: statistical analysis. Cell Viabil. Stress 33, 121-130. doi: 10.1007/s10439-0058971-x

Barron, J., Wu, P., Ladouceur, H., and Ringeisen, B. (2004). Biological laser printing: a novel technique for creating heterogeneous 3-dimensional cell patterns. Biomed. Microdev. 6, 139-147. doi: 10.1023/b:bmmd.0000031751. 67267.9f

Bazinet, A., and Popradi, G. (2019). A general practitioner's guide to hematopoietic stem-cell transplantation. Curr. Oncol. 26, 187-191.

Bhardwaj, N., and Kundu, S. C. (2010). Electrospinning: a fascinating fiber fabrication technique. Biotechnol. Adv. 28, 325-347. doi: 10.1016/j.biotechadv. 2010.01.004

Bhuthalingam, R., Lim, P. Q., Irvine, S., Agrawal, A., Mhaisalkar, P., An, J., et al. (2015). A novel 3D printing method for cell alignment and differentiation. Int. J. Bioprint. 1, 57-65.

Bieback, K., Kern, S., Klüter, H., and Eichler, H. (2004). Critical parameters for the isolation of mesenchymal stem cells from umbilical cord Blood. Stem Cells 22, 625-634. doi: 10.1634/stemcells.22-4-625

Bishop, E. S., Mostafa, S., Pakvasa, M., Luu, H. H., Lee, M. J., Wolf, J. M., et al. (2017). 3-D bioprinting technologies in tissue engineering and regenerative medicine: current and future trends. Genes Dis. 4, 185-195. doi: 10.1016/j. gendis.2017.10.002

Blaeser, A., Duarte Campos, D. F., Puster, U., Richtering, W., Stevens, M. M., and Fischer, H. (2016). Controlling shear stress in 3D bioprinting is a key factor to balance printing resolution and stem cell integrity. Adv. Healthc. Mater. 5, 326-333. doi: 10.1002/adhm.201500677

Bongso, A., Fong, C.-Y., and Gauthaman, K. (2008). Taking stem cells to the clinic: major challenges. J. Cell. Biochem. 105, 1352-1360. doi: 10.1002/jcb.21957

Butler, D. L., Goldstein, S. A., Guldberg, R. E., Guo, X. E., Kamm, R., Laurencin, C. T., et al. (2009). The Impact of Biomechanics in Tissue Engineering and Regenerative Medicine. Larchmont, NY: Mary Ann Liebert, Inc.

Byambaa, B., Annabi, N., Yue, K., Trujillo-de Santiago, G., Alvarez, M. M., Jia, W., et al. (2017). Bioprinted osteogenic and vasculogenic patterns for engineering 3D bone tissue. Adv. Healthc. Mater. 6:1700015. doi: 10.1002/adhm.201700015

Cao, H., Heazlewood, S. Y., Williams, B., Cardozo, D., Nigro, J., Oteiza, A., et al. (2016). The role of CD44 in fetal and adult hematopoietic stem cell regulation. Haematologica 101, 26-37. doi: 10.3324/haematol.2015.135921

Carrow, J. K., Kerativitayanan, P., Jaiswal, M. K., Lokhande, G., and Gaharwar, A. K. (2015). "Chapter 13-polymers for bioprinting," in Essentials of $3 D$ Biofabrication and Translation, ed. M. Haley (Amsterdam: Elsevier Inc).

Catros, S., Fricain, J.-C., Guillotin, B., Pippenger, B., Bareille, R., Remy, M., et al. (2011). Laser-assisted bioprinting for creating on-demand patterns of human osteoprogenitor cells and nano-hydroxyapatite. Biofabrication 3:025001. doi: 10.1088/1758-5082/3/2/025001

Chang, R., Nam, J., and Sun, W. (2008). Effects of dispensing pressure and nozzle diameter on cell survival from solid freeform fabrication-based direct cell writing. Tissue Eng. Part A 14, 41-48. doi: 10.1089/ten.2007.0004

Christensen, K., Xu, C., Chai, W., Zhang, Z., Fu, J., and Huang, Y. (2015). Freeform inkjet printing of cellular structures with bifurcations. Biotechnol. Bioeng. 112, 1047-1055. doi: 10.1002/bit.25501
Colwill, J. M., Cultice, J. M., and Kruse, R. L. (2008). Will generalist physician supply meet demands of an increasing and aging population? Health Aff. 27, w232-w241.

Cousin, B., Ravet, E., Poglio, S., De Toni, F., Bertuzzi, M., Lulka, H., et al. (2009). Adult stromal cells derived from human adipose tissue provoke pancreatic cancer cell death both in vitro and in vivo. PLoS One 4:e6278. doi: 10.1371/ journal.pone.0006278

Cui, X., Dean, D., Ruggeri, Z. M., and Boland, T. (2010). Cell damage evaluation of thermal inkjet printed Chinese hamster ovary cells. Biotechnol. Bioeng. 106, 963-969. doi: 10.1002/bit.22762

Dababneh, A. B., and Ozbolat, I. T. (2014). Bioprinting technology: a current state-of-the-art review. J. Manufact. Sci. Eng. 136:61016.

Daly, A. C., Freeman, F. E., Gonzalez-Fernandez, T., Critchley, S. E., Nulty, J., and Kelly, D. J. (2017). 3D bioprinting for cartilage and osteochondral tissue engineering. Adv. Healthc. Mater. 6:1700298. doi: 10.1002/adhm.201700298

Das, S., Pati, F., Choi, Y.-J., Rijal, G., Shim, J.-H., Kim, S. W., et al. (2015). Bioprintable, cell-laden silk fibroin-gelatin hydrogel supporting multilineage differentiation of stem cells for fabrication of three-dimensional tissue constructs. Acta Biomater. 11, 233-246. doi: 10.1016/j.actbio.2014.09.023

Davidenko, N., Schuster, C. F., Bax, D. V., Raynal, N., Farndale, R. W., Best, S. M., et al. (2015). Control of crosslinking for tailoring collagen-based scaffolds stability and mechanics. Acta Biomater. 25, 131-142. doi: 10.1016/j.actbio.2015. 07.034

Delgado, L. M., Bayon, Y., Pandit, A., and Zeugolis, D. I. (2015). To cross-link or not to cross-link? Cross-linking associated foreign body response of collagenbased devices. Tissue Eng. Part B Rev. 21, 298-313. doi: 10.1089/ten.teb.2014. 0290

Domingos, M., Intranuovo, F., Russo, T., De Santis, R., Gloria, A., Ambrosio, L., et al. (2013). The first systematic analysis of 3D rapid prototyped poly(E-caprolactone) scaffolds manufactured through BioCell printing: the effect of pore size and geometry on compressive mechanical behaviour and in vitro hMSC viability. Biofabrication 5:045004. doi: 10.1088/1758-5082/5/4/ 045004

Du, M., Chen, B., Meng, Q., Liu, S., Zheng, X., Zhang, C., et al. (2015). 3D bioprinting of BMSC-laden methacrylamide gelatin scaffolds with CBD-BMP2collagen microfibers. Biofabrication 7:044104. doi: 10.1088/1758-5090/7/4/ 044104

Engler, A. J., Sen, S., Sweeney, H. L., and Discher, D. E. (2006). Matrix elasticity directs stem cell lineage specification. Cell 126, 677-689. doi: 10.1016/j.cell. 2006.06.044

Freimark, D., Pino-Grace, P., Pohl, S., Weber, C., Wallrapp, C., Geigle, P., et al. (2010). Use of encapsulated stem cells to overcome the bottleneck of cell availability for cell therapy approaches. Trans. Med. Hemother. 37, 66-73.

Gao, G., Schilling, A., Hubbell, K., Yonezawa, T., Truong, D., Hong, Y., et al. (2015). Improved properties of bone and cartilage tissue from 3D inkjetbioprinted human mesenchymal stem cells by simultaneous deposition and photocrosslinking in PEG-GelMA. Biotechnol. Lett. 37, 2349-2355. doi: 10. 1007/s10529-015-1921-2

Gao, G., Schilling, A. F., Yonezawa, T., Wang, J., Dai, G., and Cui, X. (2014). Bioactive nanoparticles stimulate bone tissue formation in bioprinted threedimensional scaffold and human mesenchymal stem cells. Biotechnol. J. 9, 1304-1311. doi: 10.1002/biot.201400305

Gnecchi, M., and Melo, L. G. (2009). Bone marrow-derived mesenchymal stem cells: Isolation, expansion, characterization, viral transduction, and production of conditioned medium. Methods Mol. Biol. 482, 281-294. doi: 10.1007/978-159745-060-7_18

Goldring, C. E., Duffy, P. A., Benvenisty, N., Andrews, P. W., Ben-David, U., Eakins, R., et al. (2011). Assessing the safety of stem cell therapeutics. Cell Stem Cell 8, 618-628. doi: 10.1016/j.stem.2011.05.012

Gruene, M., Deiwick, A., Koch, L., Schlie, S., Unger, C., Hofmann, N., et al. (2011a). Laser printing of stem cells for biofabrication of scaffold-free autologous grafts. Tissue Eng. Part C Methods 17, 79-87. doi: 10.1089/ten.tec.2010.0359

Gruene, M., Pflaum, M., Deiwick, A., Koch, L., Schlie, S., Unger, C., et al. (2011b). Adipogenic differentiation of laser-printed 3D tissue grafts consisting of human adipose-derived stem cells. Biofabrication 3:015005. doi: 10.1088/1758-5082/3/ $1 / 015005$ 
Guillemot, F., Souquet, A., Catros, S., Guillotin, B., Lopez, J., Faucon, M., et al. (2010a). High-throughput laser printing of cells and biomaterials for tissue engineering. Acta Biomater. 6, 2494-2500. doi: 10.1016/j.actbio.2009.09.029

Guillemot, F., Souquet, A., Catros, S., and Guillotin, B. (2010b). Laser-assisted cell printing: principle, physical parameters versus cell fate and perspectives in tissue engineering. Nanomedicine 5, 507-515. doi: 10.2217/nnm.10.14

Grungor-Ozkerim, P. S., Inci, I., Zhang, Y. S., Khademhosseini, A., and Dokmeci, M. R. (2018). Bioinks for 3D bioprinting: an overview. Biomater. Sci. 6, 915946.

Heinrich, M. A., Liu, W., Jimenez, A., Yang, J., Akpek, A., Liu, X., et al. (2019). 3D bioprinting: from benches to translational applications. Small 15:e1805510.

Hernigou, P., Poignard, A., Beaujean, F., and Rouard, H. (2005a). Percutaneous autologous bone-marrow grafting for nonunions: influence of the number and concentration of progenitor cells. J. Bone Joint Surg. Am. 87, 1430-1437. doi: 10.2106/00004623-200507000-00003

Hernigou, P., Poignard, A., Manicom, O., Mathieu, G., and Rouard, H. (2005b). The use of percutaneous autologous bone marrow transplantation in nonunion and avascular necrosis of bone. J. Bone Joint Surg. Br. 87, 896-902. doi: 10.1302/ 0301-620x.87b7.16289

Ho, I. A., Toh, H. C., Ng, W. H., Teo, Y. L., Guo, C. M., Hui, K. M., et al. (2013). Human bone marrow-derived mesenchymal stem cells suppress human glioma growth through inhibition of angiogenesis. Stem Cells 31, 146-155. doi: $10.1002 /$ stem. 1247

Hopp, B., Smausz, T., Szabó, G., Kolozsvári, L., Kafetzopoulos, D., Fotakis, C., et al. (2012). Femtosecond laser printing of living cells using absorbing film-assisted laser-induced forward transfer. Opt. Eng. 51:014302. doi: 10.1117/1.oe.51.1. 014302

Huang, W.-H., Chang, M.-C., Tsai, K.-S., Hung, M.-C., Chen, H.-L., and Hung, S.C. (2013). Mesenchymal stem cells promote growth and angiogenesis of tumors in mice. Oncogene 32, 4343-4354. doi: 10.1038/onc.2012.458

Hyeong, J. L., Yong, B. K., Seung, H. A., Ji-Seon, L., Jang, c., Yoon, H., et al. (2015). A New Approach for Fabricating Collagen/ECM-Based Bioinks Using Preosteoblasts and Human Adipose Stem Cells. Weinheim: Wiley Subscription Services, Inc.

International Population Reports (2016). Aging World : 2015: International Population Reports. Series WP;2016 ASI 2546-17.21;Census P95/16-1. Available online at: https://statistical.proquest.com/statisticalinsight/result/ pqpresultpage.previewtitle?docType=PQSI\&titleUri=/content/2016/2546-17. 21.xml (accessed November 7, 2019).

Irvine, S., Agrawal, A., Lee, B., Chua, H., Low, K., Lau, B., et al. (2015). Printing cell-laden gelatin constructs by free-form fabrication and enzymatic protein crosslinking. Biomed. Microdev. 17, 1-8.

Irvine, S. A., and Venkatraman, S. S. (2016). Bioprinting and differentiation of stem cells. Molecules 21:1188. doi: 10.3390/molecules21091188

Jakab, K., Norotte, C., Marga, F., Murphy, K., Vunjak-Novakovic, G., Forgacs, G., et al. (2010). Tissue engineering by self-assembly and bio-printing of living cells. Biofabrication 2:022001. doi: 10.1088/1758-5082/2/2/022001

Jana, S., and Lerman, A. (2015). Bioprinting a cardiac valve. Biotechnol. Adv. 33, 1503-1521. doi: 10.1016/j.biotechadv.2015.07.006

Jóźwiak, T., Filipkowska, U., Szymczyk, P., Rodziewicz, J., and Mielcarek, A. (2017). Effect of ionic and covalent crosslinking agents on properties of chitosan beads and sorption effectiveness of Reactive Black 5 dyeReactive and Functional Polymers. Reacti. Funct. Polym. 114, 58-74. doi: 10.1016/j.reactfunctpolym. 2017.03.007

Kang, H.-W., Lee, S. J., Ko, I. K., Kengla, C., Yoo, J. J., and Atala, A. (2016). A $3 \mathrm{D}$ bioprinting system to produce human-scale tissue constructs with structural integrity. Na.t Biotechnol. 34, 312-319. doi: 10.1038/nbt.3413

Kang, L., Armstrong, P., Lee, L., Duan, B., Kang, K., and Butcher, J. (2017). Optimizing photo-encapsulation viability of heart valve cell types in $3 \mathrm{D}$ printable composite hydrogels. Ann. Biomed. Eng. 45, 360-377. doi: 10.1007/ s10439-016-1619-1

Katz, A. J., Tholpady, A., Tholpady, S. S., Shang, H., and Ogle, R. C. (2005). Cell surface and transcriptional characterization of human adipose-derived adherent stromal (hADAS) cells. Stem Cells 23, 412-423. doi: 10.1634/stemcells. 2004-0021

Keriquel, V., Oliveira, H., Rémy, M., Ziane, S., Delmond, S., Rousseau, B., et al. (2017). In situ printing of mesenchymal stromal cells, by laser-assisted bioprinting, for in vivo bone regeneration applications. Sci. Rep. 7:1778.
Khakoo, A. Y., Pati, S., Anderson, S. A., Reid, W., Elshal, M. F., Rovira, I. I., et al. (2006). Human mesenchymal stem cells exert potent antitumorigenic effects in a model of Kaposi's sarcoma. J. Exp. Med. 203, 1235-1247. doi: 10.1084/jem. 20051921

Khalil, S., and Sun, W. (2009). Bioprinting endothelial cells with alginate for 3D tissue constructs. J. Biomech. Eng. 131:111002.

Kim, M., Takaoka, A., Hoang, Q. V., Trokel, S. L., and Paik, D. C. (2014). Pharmacologic alternatives to riboflavin photochemical corneal cross-linking: a comparison studyof cell toxicity thresholds. Invest. Ophthalmol. Vis. Sci. 55, 3247-3257. doi: 10.1167/iovs.13-13703

Koch, L., Kuhn, S., Sorg, H., Gruene, M., Schlie, S., Gaebel, R., et al. (2010). Laser printing of skin cells and human stem cells. Tissue Eng. Part C Methods 16, 847-854. doi: 10.1089/ten.tec.2009.0397

Kucerova, L., Matuskova, M., Hlubinova, K., Altanerova, V., and Altaner, C. (2010). Tumor cell behaviour modulation by mesenchymal stromal cells. Mol. Cancer 9:129. doi: 10.1186/1476-4598-9-129

Kuznetsov, S. A., Mankani, M. H., Gronthos, S., Satomura, K., Bianco, P., and Robey, P. G. (2001). Circulating skeletal stem cells. J. Cell Biol. 153, 1133-1140.

Kyle, H. V., Stafford, A., and Mooney, D. J. (2019). Sequential modes of crosslinking tune viscoelasticity of cell-instructive hydrogels. Biomaterials 188, 187-197. doi: 10.1016/j.biomaterials.2018.10.013

Lane, S. W., Williams, D. A., and Watt, F. M. (2014). Modulating the stem cell niche for tissue regeneration. Nat. Biotechnol. 32, 795-803. doi: 10.1038/nbt.2978

Langer, R., and Vacanti, J. P. (1993). Tissue engineering. Science 260, 920-926.

Leberfinger, A. N., Ravnic, D. J., Dhawan, A., and Ozbolat, I. T. (2017). Concise review: bioprinting of stem cells for transplantable tissue fabrication. pISSN 6, 1940-1948. doi: 10.1002/sctm.17-0148

Lee, H. J., Kim, Y. B., Ahn, S. H., Lee, J., Jang, C. H., Yoon, H., et al. (2015). A new approach for fabricating collagen/ECM-based bioinks using preosteoblasts and human adipose stem cells. Adv. Healthc. Mater. 4, 1359-1368. doi: 10.1002/ adhm.201500193

Levato, R., Visser, J., Planell, J. A., Engel, E., Malda, J., and Mateos-Timoneda, M. A. (2014). Biofabrication of tissue constructs by 3D bioprinting of cell-laden microcarriers. Biofabrication 6:035020. doi: 10.1088/1758-5082/6/3/035020

Lew, D. H., Liu, P. H., and Orgill, D. P. (2007). Optimization of UV cross-linking density for durable and nontoxic collagen gag dermal substitute. J. Biomed. Mater. Res. B Appl. Biomater. 82, 51-56. doi: 10.1002/jbm.b.30704

Li, J., Chen, M., Fan, X., and Zhou, H. (2016). Recent advances in bioprinting techniques: approaches, applications and future prospects. J. Transl. Med. $14: 271$.

Lim, K. S., Schon, B. S., Mekhileri, N. V., Brown, G. C. J., Chia, C. M., Prabakar, S., et al. (2016). New visible-light photoinitiating system for improved print fidelity in gelatin-based bioinks. ACS Biomater. Sci. Eng. 2, 1752-1762. doi: 10.1021/acsbiomaterials.6b00149

Mackay, A. M., Beck, S. C., Murphy, J. M., Barry, F. P., Chichester, C. O., Pittenger, M. F., et al. (1998). Chondrogenic differentiation of cultured human mesenchymal stem cells from marrow. Tissue Eng. 4, 415-428.

Maher. P., Keatch, R., Donnelly, K., Mackay, R., and Paxton, J. (2009). Construction of 3D biological matrices using rapid prototyping technology. Rapid Prototyp. J. 15, 204-210. doi: 10.1108/13552540910960307

Mairim, A. S., Chen, Y. H., Wong, T. Y., Bittencourt, V., Lin, Y. C., and Huang, L. (2012). Hyaluronan regulates cell behavior: A potential niche matrix for stem cells. Biochem. Res. Int. 2012:346972-11. doi: 10.1155/2012/346972

Mandrycky, C., Wang, Z., Kim, K., and Kim, D. -H. (2016). 3D bioprinting for engineering complex tissues. Biotechnol. Adv. 34, 422-434. doi: 10.1016/j. biotechadv.2015.12.011

Matsiko, A., Gleeson, J. P., and O’Brien, F. J. (2015). Scaffold mean pore size influences mesenchymal stem cell chondrogenic differentiation and matrix deposition. Tissue Eng. Part A 21, 486-497. doi: 10.1089/ten.tea.2013.0545

Melchels, F. P., Barradas, A. M., van Blitterswijk, C. A., de Boer, J., Feijen, J., Grijpma, D. W., et al. (2010). Effects of the architecture of tissue engineering scaffolds on cell seeding and culturing. Acta Biomater. 6, 4208-4217. doi: 10.1016/j.actbio.2010.06.012

Minteer, D., Marra, K. G., and Rubin, J. P. (2013). Adipose-derived mesenchymal stem cells: biology, and potential applications. Adv. Biochem. Eng. Biotechnol. 129, 59-71. doi: 10.1007/10_2012_146 
Mondschein, R. J., Kanitkar, A., Williams, C. B., Verbridge, S. S., Long, T. E., et al. (2017). Polymer structure-property requirements for stereolithographic 3D printing of soft tissue engineering scaffolds. Biomaterials 140, 170-188. doi: 10.1016/j.biomaterials.2017.06.005

Murphy, S. V., and Atala, A. (2014). 3D bioprinting of tissues and organs. Nat. Biotechnol. 32, 773-785. doi: 10.1038/nbt.2958

Muzzarelli, R. A., El Mehtedi, M., Bottegoni, C., Aquili, A., and Gigante, A. (2015). Genipin-crosslinked chitosan gels and scaffolds for tissue engineering and regeneration of cartilage and bone. Mar. Drugs 13, 7314-7338. doi: 10. 3390/md13127068

Nakamura, M., Kobayashi, A., Takagi, F., Watanabe, A., Hiruma, Y., Ohuchi, K., et al. (2005). Biocompatible inkjet printing technique for designed seeding of individual living Cells. Tissue Eng. 11, 1658-1666. doi: 10.1089/ten.2005.11. 1658

Ong, C. S., Yesantharao, P., Huang, C. Y., Mattson, G., Boktor, J., Fukunishi, T., et al. (2018). 3D bioprinting using stem cells. Pediatr. Res. 83, 223-231. doi: $10.1038 /$ pr.2017.252

Oryan, A., Kamali, A., Moshiri, A., Baharvand, H., and Daemi, H. (2018). Chemical crosslinking of biopolymeric scaffolds: current knowledge and future directions of crosslinked engineered bone scaffolds. Int. J. Biol. Macromol. 107(Pt A):678688. doi: 10.1016/j.ijbiomac.2017.08.184

Ozbolat, I. T., and Hospodiuk, M. (2015). Current advances and future perspectives in extrusion-based bioprinting. Biomaterials 76, 321-343. doi: 10.1016/j. biomaterials.2015.10.076

Parvin, S., Noorjahan, B. A., Abdul, M. A., Abdul, R. O., Maryam, M., Ehsan, J., et al. (2012). Comparison of different methods for the isolation of mesenchymal stem cells from human umbilical cord Wharton's jelly. In Vitro Cell Dev. Biol. Anim. 48, 75-83. doi: 10.1007/s11626-011-9480-x

Perrot, P., Rousseau, J., Bouffaut, A. L., Rédini, F., Cassagnau, E., Deschaseaux, F., et al. (2010). Safety concern between autologous fat graft, mesenchymal stem cell and osteosarcoma recurrence. PLoS One 5:e10999. doi: 10.1371/journal. pone.0010999

Pfeiffer, E., Vickers, S. M., Frank, E., Grodzinsky, A. J., and Spector, M. (2008). The effects of glycosaminoglycan content on the compressive modulus of cartilage engineered in type II collagen scaffolds. Osteoarthr. Cartil. 16, 1237-1244. doi: 10.1016/j.joca.2008.02.014

Phillippi, J. A., Miller, E., Weiss, L., Huard, J., Waggoner, A., Campbell, P., et al. (2008). Microenvironments engineered by inkjet bioprinting spatially direct adult stem cells toward muscle- and bone-like subpopulations. Stem Cells 26, 127-134. doi: 10.1634/stemcells.2007-0520

Pintus, E., Baldassarri, M., Perazzo, L., Natali, S., Ghinelli, D., Buda, R., et al. (2018). Stem cells in osteochondral tissue engineering. Adv. Exp. Med. Biol. 1058, 359-372. doi: 10.1007/978-3-319-76711-6_16

Porada, C., Zanjani, E. D., and Almeida-Porad, G. (2006). Adult mesenchymal stem cells: a pluripotent population with multiple applications. Stem Cell Res. Ther. 1, 365-369. doi: 10.2174/157488806778226821

Pountos, I., Corscadden, D., Emery, P., and Giannoudis, P. V. (2007). Mesenchymal stem cell tissue engineering: Techniques for isolation, expansion and application. Injury 38:S33. doi: 10.1016/S0020-1383(08)70006-8

Qi, D., Wu, S., Kuss, M. A., Shi, W., Chung, S., Deegan, P. T., et al. (2018). Mechanically robust cryogels with injectability and bioprinting supportability for adipose tissue engineering. Acta Biomater. 74, 131-142. doi: 10.1016/j. actbio.2018.05.044

Rak Kwon, D., Jung, S., Jang, J., Park, G. Y., Suk Moon, Y., Lee, S. C., et al. (2020). A 3-dimensional bioprinted scaffold with human umbilical cord bloodmesenchymal stem cells improves regeneration of chronic full-thickness rotator cuff tear in a rabbit model. Am. J. Sports Med. 48, 947-958. doi: 10.1177/ 0363546520904022

Raman, R., Bhaduri, B., Mir, M., Shkumatov, A., Lee, M. K., Popescu, G., et al. (2016). High-resolution projection microstereolithography for patterning of neovasculature. Adv. Healthcare Mater. 5, 610-619. doi: 10.1002/adhm. 201500721

Raucci, M. G., Alvarez-Perez, M. A., Demitri, C., Giugliano, D., De Benedictis, V., Sannino, A., et al. (2015). Effect of citric acid crosslinking cellulose-based hydrogels on osteogenic differentiation. J. Biomed. Mater. Res. A. 103, $2045-$ 2056. doi: 10.1002/jbm.a.35343

Rowlands, A. S., George, P. A., and Cooper-White, J. J. (2008). Directing osteogenic and myogenic differentiation of MSCs: interplay of stiffness and adhesive ligand presentation. Am. J. Physiol. Cell Physiol. 295, 1037-1044. doi: 10.1152/ajpcell. 67.2008

Rubio, D., Garcia-Castro, J., Martin, M. C., de la Fuente, R., Cigudosa, J. C., Lloyd, A. C., et al. (2005). Spontaneous human adult stem cell transformation. Cancer Res. 65, 3035-3039. doi: 10.1158/0008-5472.CAN-04-4194

Ryu, S., Yoo, J., Jang, Y., Jin, H., Jung, SY., Park, J., et al. (2015). Nanothin coculture membranes with tunable pore architecture and thermoresponsive functionality for transfer-printable stem cell-derived cardiac sheets. ACS Nano 9, 10186-10202. doi: 10.1021/acsnano.5b03823

Sasaki, M., Abe, R., Fujita, Y., Ando, S., Inokuma, D., and Shimizu, H. (2008). Mesenchymal stem cells are recruited into wounded skin and contribute to wound repair by trans differentiation into multiple skin cell type. J. Immunol. 180, 2581-2587. doi: 10.4049/jimmunol.180.4.2581

Saunders, R. E., Gough, J. E., and Derby, B. (2007). Delivery of human fibroblast cells by piezoelectric drop-on-demand inkjet printing. Biomaterials 29, $193-$ 203. doi: 10.1016/j.biomaterials.2007.09.032

Seetharam, R. (1991). "Purification and analysis of recombinant proteins," in Bioprocess Technology (New York, NY: Dekker).

Shav, D., and Einav, S. (2010). The effect of mechanical loads in the differentiation of precursor cells into mature cells. Ann. N. Y. Acad. Sci. 1188, 25-31. doi: 10.1111/j.1749-6632.2009.05079.x

Shahabipour, F., Ashammakhi, N., Oskuee, R. K., Bonakdar, S., Hoffman, T., Shokrgozar, M. A., et al. (2020). Key components of engineering vascularized 3-dimensional bioprinted bone constructs. Transl Res. 216, 57-76 doi: 10.1016/ j.trsl.2019.08.010

Skardal, A., and Atala, A. (2015). Biomaterials for Integration with 3-D Bioprinting. Biomed. Eng. 43, 730-746. doi: 10.1007/s10439-014-1207-1

Sotiropoulou, P. A., Perez, S. A., Salagianni, M., Baxevanis, C. N., and Papamichail, M. (2006). Characterization of the optimal culture conditions for clinical scale production of human mesenchymal stem cells. Stem Cells 24, 462-471. doi: 10.1634/stemcells.2004-0331

Stolberg, S., and McCloskey, K. E. (2009). Can shear stress direct stem cell fate? Cell Culture Tissue Eng. 25, 10-19. doi: 10.1002/btpr.124

Suzuki, K., Sun, R., Origuchi, M., Kanehira, M., Takahata, T., Itoh, J., et al. (2011). "Mesenchymal stromal cells promote tumor growth through the enhancement of neovascularization," in Molecular Medicine, Vol. 17 (Cambridge, MA), 579587. doi: 10.2119/molmed.2010.00157

Tasnim, N., De la Vega, L., Kumar, S. A., Abelseth, L., Matthew Alonzo, M., et al. (2018). 3D bioprinting stem cell derived tissues. Cell Mol. Bioeng. 11, 219-240. doi: 10.1007/s12195-018-0530-2

Thompson, W. R., Rubin, J., and Rubin, C. T. (2012). Mechanical regulation of signaling pathways in bone. Gene 503, 179-193. doi: 10.1016/j.gene.2012.04.076

Trombetta, R., Inzana, J., Schwarz, E., Kates, S., and Awad, H. (2017). 3D printing of calcium phosphate ceramics for bone tissue engineering and drug delivery. Ann. Biomed. Eng. 45, 23-44. doi: 10.1007/s10439-0161678-3

Trounson, A., and McDonald, C. (2015). Stem cell therapies in clinical trials: Progress and challenges. Cell Stem Cell 17, 11-22. doi: 10.1016/j.stem.2015.06. 007

Tsai, M. S., Lee, J. L., Chang, Y. J., and Hwang, S. M. (2004). Isolation of human multipotent mesenchymal stem cells from second-trimester amniotic fluid using a novel two-stage culture protocol. Hum. Reprod. 19, 1450-1456. doi: 10.1093/humrep/deh279

Tsuji, K., Ojima, M., Otabe, K., Horie, M., Koga, H., Sekiya, I., et al. (2017). Effects of different cell-detaching methods on the viability and cell surface antigen expression of synovial mesenchymal stem cells. Cell Transplant. 26, 1089-1102. doi: 10.3727/096368917X694831

Tuszynski, M. H., Wang, Y., Graham, L., Gao, M., Wu, D., Brock, J., et al. (2014). Neural stem cell dissemination after grafting to CNS injury sites. Cell 156, 388-389. doi: 10.1016/j.cell.2014.01.016

Vining, K. H., Stafford, A., and Mooney, D. J. (2019). Sequential modes of crosslinking tune viscoelasticity of cell-instructive hydrogels. Biomaterials 188 , 187-197. doi: 10.1016/j.biomaterials.2018.10.013

Visser, J., Melchels, F., and Jeon, J. (2015). Reinforcement of hydrogels using three-dimensionally printed microfibres. Nat. Commun. 6:6933. doi: 10.1038/ ncomms7933

Wang, H. L., Zuo, Y., Li, Y., Ma, J., and Cheng, S. L. (2007). Biocompatibility and osteogenesis of biomimetic nano-hydroxyapatite/polyamide composite 
scaffolds for bone tissue engineering. Biomaterials 28, 3338-3348. doi: 10.1016/ j.biomaterials.2007.04.014

Wang, L., and Stegemann, J. P. (2011). Glyoxal crosslinking of cell-seeded chitosan/collagen hydrogels for bone regeneration. Acta Biomater. 7, 24102417. doi: 10.1016/j.actbio.2011.02.029

Wang, Z., Abdulla, R., Parker, B., Samanipour, R., Ghosh, S., and Kim, K. (2015). A simple and high-resolution stereolithography-based 3D bioprinting system using visible light crosslinkable bioinks. Biofabrication 7:045009. doi: 10.1088/ 1758-5090/7/4/045009

Willerth, S. M., and Sakiyama-Elbert, S. (2008). Cell therapy for spinal cord regeneration. Drug. Deliv. Rev. 60, 263-276. doi: 10.1016/j.addr.2007. 08.028

Wüst, S., Godla, M. E., Müller, R., and Hofmann, S. (2014). Tunable hydrogel composite with two-step processing in combination with innovative hardware upgrade for cell-based three-dimensional bioprinting. Acta Biomater. 10, 630640. doi: 10.1016/j.actbio.2013.10.016

Wüst, S., Müller, R., and Hofmann Boss, S. S. (2011). Controlled positioning of cells in biomaterials - approaches towards 3D tissue printing. J. Funct. Biomater. 2:119.

Xu, T., Jin, J., Gregory, C., Hickman, J. J., and Boland, T. (2005). Inkjet printing of viable mammalian cells. Biomaterials 26, 93-99. doi: 10.1016/j.biomaterials. 2004.04.011

Yanagi, Y., Nakayama, K., Taguchi, T., Enosawa, S., Tamura, T., Yoshimaru, K., et al. (2017). In vivo and ex vivo methods of growing a liver bud through tissue connection. Sci. Rep. 7:14085. doi: 10.1038/s41598-017-14542-2
Young, H. E., Mancini, M. L., Wright, R. P., Smith, J. C., Black, A. C. Jr, Reagan, C. R., et al. (1995). Mesenchymal stem cells reside within the connective tissues of many organs. Dev. Dyn. 202, 137-144. doi: 10.1002/aja.1002020205

Yuan, X., Logan, T. M., and Ma, T. (2019). Metabolism in human mesenchymal stromal cells: A missing link between hMSC Biomanufacturing and therapy? Front. immunol. 10:977. doi: 10.3389/fimmu.2019.00977

Zhao, Y., Li, Y., Mao, S., Sun, W., and Yao, R. (2015). The influence of printing parameters on cell survival rate and printability in microextrusion-based 3D cell printing technology. Biofabrication 7:045002. doi: 10.1088/1758-5090/7/4/ 045002

Zhao, Y., Yao, R., Ouyang, L., Ding, H., Zhang, T., Zhang, K., et al. (2014). Three-dimensional printing of Hela cells for cervical tumor model in vitro. Biofabrication 6:035001. doi: 10.1088/1758-5082/6/3/035001

Conflict of Interest: The authors declare that the research was conducted in the absence of any commercial or financial relationships that could be construed as a potential conflict of interest.

Copyright (c) 2020 Belk, Tellisi, Macdonald, Erdem, Ashammakhi and Pountos. This is an open-access article distributed under the terms of the Creative Commons Attribution License (CC BY). The use, distribution or reproduction in other forums is permitted, provided the original author(s) and the copyright owner(s) are credited and that the original publication in this journal is cited, in accordance with accepted academic practice. No use, distribution or reproduction is permitted which does not comply with these terms. 